\title{
Effects of Intra-Articular Platelet- Rich Plasma Administration in Temporomandibular Joint Arthritis: An Experimental Study
}

\author{
Temporomandibüler Eklem Artritinde Intrartiküler Trombositten \\ Zengin Plazma Kullanımının Etkisi: Sı çanlarda Deneysel Çalışma
}

(D) Heval Selman Özkan ${ }^{1}$, (D) Saime İrkören ${ }^{1}$, (D) Huray Karaca ${ }^{1}$, (D) Taha Deniz Yıldırım¹, (D) Kadir Çiçek ${ }^{1}$, (D) Canten Tataroğlu

${ }^{1}$ Adnan Menderes University Faculty of Medicine, Department of Plastic and Reconstructive Surgery, Aydın, Turkey

${ }^{2}$ Adnan Menderes University Faculty of Medicine, Department of Pathology, Aydın, Turkey

Keywords

Temporomandibular joint, platelet rich plasma, osteoarthritis

Anahtar Kelimeler

Temporomandibüler eklem, trombositten

zengin plazma, osteoartrit

Received/Geliş Tarihi : 20.03.2017

Accepted/Kabul Tarihi : 20.11.2017

doi:10.4274/meandros.29484

Address for Correspondence/Yazışma Adresi: Heval Selman Özkan MD, Adnan Menderes University Faculty of Medicine, Department of Plastic and Reconstructive Surgery,

Aydın,Turkey

Phone : +90 2562441256

E-mail : selman_ozk@yahoo.com

ORCID ID: orcid.org/0000-0003-0345-5847

(C) Meandros Medical and Dental Journal, Published by Galenos Publishing House.

This is article distributed under the terms of the

Creative Commons Attribution NonCommercial 4.0

International Licence (CC BY-NC 4.0).

\begin{abstract}
Objective: Osteoarthritis is defined as a disease that begins with focal and progressive destruction in articular cartilage with biomechanical, biochemical, inflammatory and immunologic reactions and may cause pathologic changes in the subchondral bone and joints. The platelet-rich plasma accelerates wound and bone healing in clinical trials; decreases swelling, pain, infection and scarring; and controls bleeding. In this study, we studied the effect of intraarticular thrombocyterich plasma administration in the model of temporomandibular osteoarthritis induced by monosodium iodoacetate (MAl) injection.

Materials and Methods: Forty-five Wistar male rats were used in the study. The rats were divided into 3 groups, each containing eight animals. In the first group, only serum physiologic injections were performed to the temporomandibular joints and identified as the control group. In the second group, arthritis model was created by injecting MAI to the temporomandibular joint. Third group was the study group intraarticular platelet rich plasma injections were performed 4 weeks after monosodium iodoacetate injections.

Results: When cartilage thicknesses were evaluated, there was a significant decrease in group 3 arthritis when compared with other groups. In the study group, cartilage thickness was not significantly different from control groups, but statistically significant improvement was observed when compared to monosodium idoacetate group. Although subchondral cyst formations were also observed in the study group a statistically significant difference was observed between the arthritis group.

Conclusion: We believe that our study results support, and enlightens therapeutic effects of platelet rich plasma on temporomandibular joint arthritis.
\end{abstract}

Öz

Amaç: Osteoartrit biyomekanik, biyokimyasal, enflamatuvar ve immünolojik reaksiyonların etkisiyle, artiküler kartilajda fokal ve progresif yıkım ile başlayan, subkondral kemikte ve eklem yapılarının tamamında patolojik değişikliklere neden olabilen bir hastalık olarak tanımlanmaktadır. Trombositten zengin plazmanın yapılan klinik çalışmalarda yara ve kemik iyileşmesini hızlandırdığı; şişliği, ağrıyı, enfeksiyonu ve skarı azalttığı; kanama kontrolü sağladığı iddia edilmektedir. Biz 
bu çalışmada monosodyum iyodoasetat (MAI) enjeksiyonu ile oluşturulmuş temporomandibüler osteoartrit modelinde intrartiküler trombositten zengin plazma kullanımının etkisini araştırdık.

Gereç ve Yöntemler: Çalışmada 45 adet Wistar tipi erkek sıçan kullanıldı. Sıçanlar her biri sekizer hayvan içerecek şekilde 3 gruba ayrıldı. 1. grupta temporomandibüler ekleme sadece serum fizyolojik enjeksiyonu yapıldı ve kontrol grubu olarak belirlendi. 2. grupta temporomandibüler ekleme MAI enjeksiyonu yapılarak artrit modeli oluşturuldu. Üç grup deney çalışma grubu olarak belirlendi ve monosodyum iyodoasetat enjeksiyonundan 4 hafta sonra intraartiküler trombositten zengin plazma enjeksiyonları yapıldı.

Bulgular: Kıkırdak kalınlıkları değerlendirildiğinde 3. grup artrit grubunda diğer tüm gruplara göre anlamlı derecede azalma mevcuttu. Çalışma grubunda ise kıkırdak kalınlığında kontrol grupları ile anlamlı bir fark bulunmazken, monosodyum iyodoacetat grubuna göre istatistiksel olarak anlamlı iyileşme izlendi. Yine kist oluşumları çalışma grubunda da izlenmesine rağmen, artrit grubu ile arasında istatistiksel olarak anlamlı fark izlendi.

Sonuç: Çalışmamızın trombositten zengin plazmanın temporomandibüler eklem artriti üzerindeki iyileştirici etkileri üzerinde aydınlatıcı ve klinik kullanımı destekleyici olabileceğini düşünüyoruz.

\section{Introduction}

Osteoarthritis (OA) is a disease defined with focal and progressive destruction in articular cartilage with the effects of multifactorial reactions and can cause pathologic subchondral bone involvement and joint structures (1). Female patients are commonly affected from temporomandibular joint (TMJ) $\mathrm{OA}$ and TMJ dysfunction. Chronic pain, synovitis, cartilage degradation and bone remodeling occurs in pathologic process of OA (2). One major difference of condylar cartilage in the TMJ from other synovial joints is the presence of fibrocartilage containing thick, multi-layered collagen. The degenerative changes of cartilage affect the ability to change physical properties and to resist compression and shear stress. Increased friction between articulating surfaces can cause joint movements to deteriorate and lead to pathological responses to adjacent tissues such as cartilage, capsule, ligaments, synovial membranes, subchondral bone and muscles $(3,4)$.

Many surgical and non-surgical modalities have been proposed and used in the literature, yet no universally accepted treatment exists. TMJ OA continues to be a serious and wide health problem causing significant morbidity (5).

To evaluate TMJ OA pathogenesis and potential treatment strategies an animal model is essential. Mechanical, surgical, spontaneous occurring and drug induced models have been reported in the literature. Knee joint OA model have been successfully induced with intra-articular injection of monosodium iodoacetate (MIA) and widely accepted in literature. There is some recent literature on the use of MIA for creation of both rabbit and rat TMJ OA $(6,7)$.
Platelet-rich plasma (PRP) is a solution formed by centrifugation and condensation of blood, containing high concentrations of platelets. The amount of platelet obtained is 3-8 times that of normal plasma. A large number of mediators are released from the $\alpha$-granules of these platelets by the addition of thrombin or other activators. PRP contains growth factors such as vascular endothelial growth factor (VEGF), platelet derived growth factor (PDGF), transforming growth factor $\alpha$ and $\beta$ (TGF $\alpha$ and $\beta$ ), epidermal growth factor (EGF), fibroblast growth factor (FGF), insulin like growth factor (IGF). Almost all these mediators are involved in wound and bone healing and are also effective on angiogenesis. Clinical trials showed that it accelerates the bone and wound healing, decreases swelling, pain, infection and scar formation, and helps hemostasis $(8,9)$.

Because autologous derivation and relatively safe application this product has been used clinically without adequate experimental study. It promises a lot theoretically but still has suspicions due to lack of enough controlled studies. In this study, we investigated the effect of intraarticular injection of PRP in the TMJ OA model induced by MIA injection.

\section{Materials and Methods}

This experiment was carried out in the animal laboratory of Adnan Menderes University Faculty of Medicine and approved by Adnan Menderes University Faculty of Medicine Animal Ethics Committee (no: 64583101-2015-113). All experimental procedures were carried out in accordance with the Laboratory Animal Care and Use Health Guide National Institutes. In the study, 35 Wistar male rats (300 and 350 grams) were used. All rats were housed with a 12-12 h light-dark cycle (artificial lighting) with an ambient 
temperature of $22 \pm 20{ }^{\circ} \mathrm{C}$. Animal feeding needs were regularly met by standard laboratory food and water. All rats were anaesthetized by intramuscular injection with a mixture of $\% 10$ ketamin hydrochloride $(\mathrm{HCl})$ (50 mg/kg- Alfamine $\left.{ }^{\circledR}-\mathrm{IM}\right)$ and Xylazin $\mathrm{HCl}(2,5 \mathrm{mg} /$ kg- Rompun ${ }^{\circledR}-\mathrm{IM}$ ) during all experimental procedures done by the same surgeon. The experiment was performed after 1-month adaptation period. The rats were divided into 3 groups, each containing eight animals. No injections were made in left sides of the animals. Only intraarticular SF injections were performed in group 1. In group 2, intraarticular MIA injections were performed to create arthritis model. Third group was determined as the study group and intra-articular PRP injections were performed at 4 th week after MIA injection.

\section{Preparation of the Platelet-Rich Plasma Solution}

Blood required to separate platelets from other blood components and plasma to produce PRP was obtained by intra-cardiac cannulation of 11 selected donor rats under anesthesia with a mixture of ketamine $\mathrm{HCl}$ (Alfamine ${ }^{\circledR}-\mathrm{IM}$ ) and xylazine $\mathrm{HCl}$ (Rompun ${ }^{\circledR}-\mathrm{IM}$ ).

$100 \mathrm{~mL}$ of blood was collected in four tubes for centrifugation by mixing with citrate-phosphatedextrose (CPD) solution at $5 \mathrm{~mL}$ blood/1 $\mathrm{mL}$ CPD ratio to prevent clotting. The CPD solution used was obtained from triple blood bags (Baxter Healthcare Corp, USA) in blood centers. Pooled blood was subjected to centrifugation for 20 minutes at a temperature of $220{ }^{\circ} \mathrm{C}$ and a $200 \mathrm{~g}$ cycle centrifuge (Heraeus Cryofuge 6000i, Kendo Laboratory Products). A thin intermediate layer (buffy coat) was observed between the light-yellow plasma collected at the top and the red layer at the bottom. This intermediate layer together with the plasma on it was transferred to a separate tube. The tube was centrifuged for 20 minutes at $480 \mathrm{rpm}$ for a second time. The resulting platelet concentrate and platelet poor plasma (= fibrin glue $=F G$ ) were separated and taken into different tubes. The platelet concentrate was diluted with FG to $1.5 \times 1012$ platelets/L. Since platelet-rich plasma contained leucocytes in it and was not able to use autologous products in each animal in the study, lymphocyte inactivation was achieved by irradiation with 25 Gy to reduce the "graft versus host" reaction. Platelet rich plasma was activated with bovine thrombin preparation (Thrombin, Sigma-
Aldrich, Germany). Thousand units of powdered thrombin containing product was mixed with $10 \mathrm{ml}$ of $10 \%$ calcium chloride to obtain thrombin solution at a rate of 100 units $/ \mathrm{mL}$. Ten-unit thrombin solution was added to $1 \mathrm{~mL}$ of PRP. So that PRP activation and release of growth factors were achieved.

\section{Preparation of Arthritis Model}

In $2^{\text {nd }}$ and $3^{\text {th }}$ groups, MIA solution was injected to the TMJs upper compartment to induce TMJ OA. To confirm injection site firstly dye injection of $50 \mathrm{~mL}$ was performed to the upper compartment. Than 0.5 mg MIA injection was performed to the right upper compartment TMJs. Left TMJs were left as controls.

Study group was formed by injection into the right TMJs. After 4 weeks, the PRP solution prepared as described above was applied to the MIA injected group. Twelve weeks after the first injection, all rats were sacrificed, exploration was performed, and specimens were taken for histopathological examination. TMJ tissues were completely removed with the surrounding tissues. Samples were taken from the anterior, posterior and lateral sides of the joints and each sample was left in $10 \%$ formalin for 24 hours. $5 \mathrm{~mm}$ of thick sections were taken from each sample and stained with hematoxylin and eosin (H\&E), Masson trichom. Inflammatory changes are classified as $0=$ no inflammation; $1=$ mild inflammation (mild congestion and oedema); $2=$ =moderate inflammation (congestion and oedema, small amount of neutrophil leukocytes); $3=$ severe inflammation (numerous neutrophils and macrophages). Inflammation, subchondral cyst formation and cartilage thicknesses were examined by the same pathologist under microscope $(x 100$ magnification). Statistical comparison of all these data was performed.

\section{Statistical Analysis}

Statistical analyses were performed with SPSS (SPSS Inc, USA v 16.0). The mean \pm was show standard error of mean, and Mann-Whitney $U$ test and Pearson chi-square were used to compare the groups. $\mathrm{P}<0.05$ was statistically significant.

\section{Results}

Groups were evaluated for cartilage thickness, inflammation and subchondral cyst formation (Figure 1). When the cartilage thickness was evaluated, there was a significant decrease in the second group 

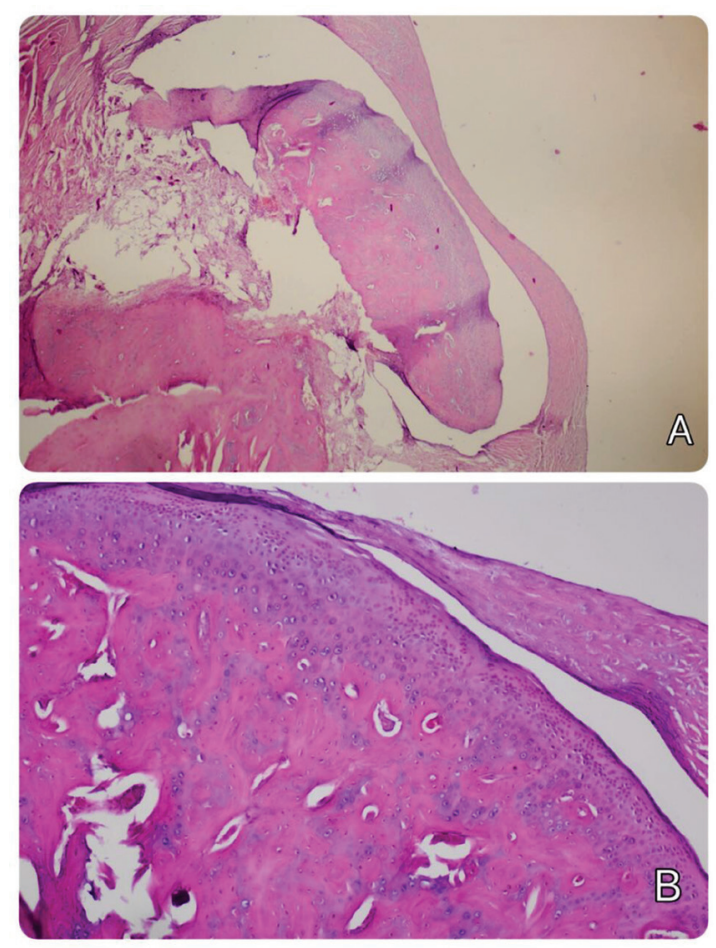

Figure 1. A) Normal temporomandibular joint, cartilage and joint, x20, hematoxylin and eosin. B) Normal joint architecture $\mathrm{x} 100$, hematoxylin and eosin

compared to other groups. In the study group, there was no statistically significant difference in cartilage thickness compared to the control group, but a statistically significant improvement exists when compared to the MIA group. Cartilage thickness was found to be significantly decreased in the arthritis group compared to the other groups and no significant difference was found between the other groups (Figure 2) (Graphic 1).

Inflammation was found to be significantly increased in the MIA group. Also, an increased number of subchondral cyst formations were observed in the MIA group compared to other groups. Although cyst formations were also observed in the study group, there was a statistically significant difference with the arthritis group (Figure 2) (Tables 1, 2).

\section{Discussion}

TMJ diseases are very common spectrum disorders and $O A$ is reported as an important subtype. In the pathogenesis of this disease, there are changes in the subchondral bone and joint structures, beginning with focal and progressive destruction in the articular
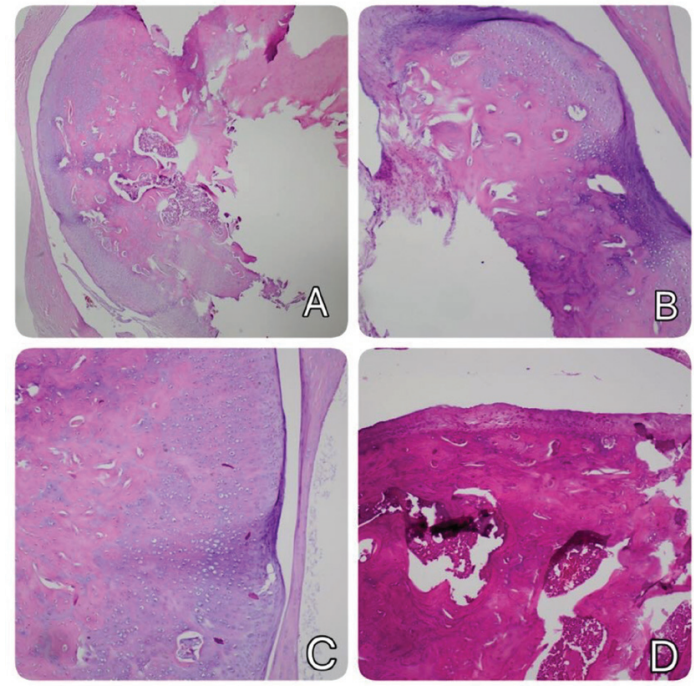

Figure 2. A) Increased trabecular bone, x40, hematoxylin and eosin. B) Subchondral cyst formations in monoamine iodoacetate group, x100, hematoxylin and eosin. C) Increased cartilage thickness in platelet-rich plasma group, $x 200$, hematoxylin and eosin. D) Thin and deformed cartilage and increased trabeculation in monoamine iodoacetate group, $x 100$, hematoxylin and eosin

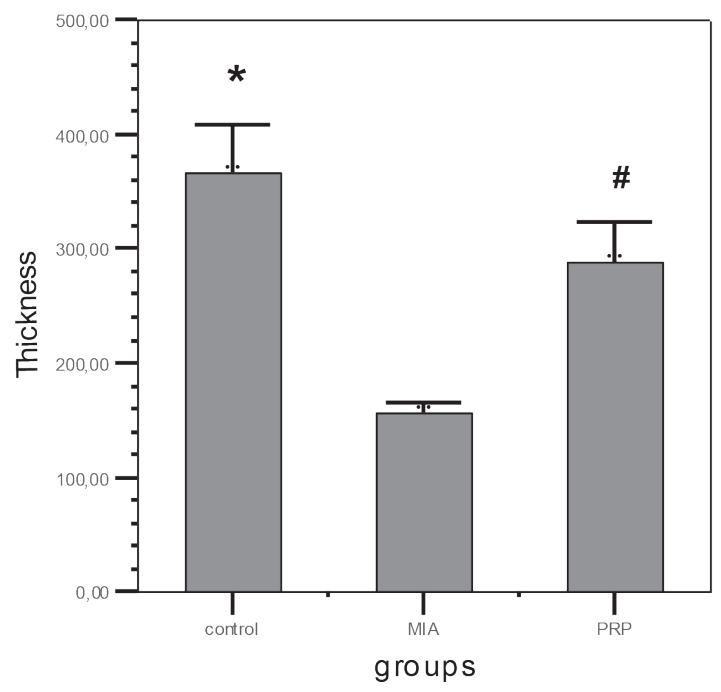

Graphic 1. Temporomandibular cartilage thicknesses of the groups

${ }^{*} p<0.05$ control vs MIA, \#p<0.05 control vs PRP

MIA: Monoamine iodoacetate, PRP: Platelet-rich plasma

cartilage with the effects of the inflammatory and immunological reactions (10).

Until now, TMJ OA animal models have been tried to be formed by various methods including surgical, mechanical, drug-induced and spontaneously occurring methods. Surgically induced and 


\begin{tabular}{|l|l|l|l|l|}
\hline \multicolumn{2}{|l|}{ Table 1. Subchondral cyst formation in groups } \\
\hline & \multicolumn{4}{l|}{ Groups } \\
\cline { 2 - 6 } & Control & MIA & PRP & Total \\
\hline Subchondral cysts* (-) & 7 & 0 & 5 & 12 \\
\hline Subchondral cysts (+) & 1 & 8 & 3 & 12 \\
\hline Total & 8 & 8 & 8 & 24 \\
\hline
\end{tabular}

Subchondral cysts groups Crosstabulation: ${ }^{*} p<0.05$ compared three groups. MIA: Monoamine iodoacetate, PRP: Platelet-rich plasma

\begin{tabular}{|l|l|l|l|l|}
\hline Table 2. Inflammation in groups \\
\hline \multirow{2}{*}{ Inflammation grade* } & Groups \\
\cline { 2 - 5 } & Control & MIA & PRP & Total \\
\hline 0 & 6 & 0 & 0 & 6 \\
\hline 1 & 2 & 0 & 5 & 7 \\
\hline 2 & 0 & 3 & 3 & 6 \\
\hline 3 & 0 & 5 & 0 & 5 \\
\hline Total & 8 & 8 & 8 & 24 \\
\hline $\begin{array}{l}\text { Inflammation groups Crosstabulation: * } p<0.05 \text { compared three groups. } \\
\text { MIA: Monoamine iodoacetate, PRP: Platelet-rich plasma }\end{array}$ \\
\hline
\end{tabular}

spontaneous methods are limited due to slow progression and complicated operative nature of TMJ. Therefore, studies focusing drug-induced models to be cartilage damage models instead of OA models. A simple and reproducible animal model of TMJ OA that mimics clinically and histopathologically is still necessary (11).

MIA injections are widely used in the literature to induce OA-like lesions in knee joints.

MIA mainly inhibits glyceraldehyde-3-phosphate dehydrogenase activity and leads to apoptosis of chondrocytes. With the modification of the MIA concentration, the progression of articular lesions and the severity of lesions can be easily modulated. In experimental researches and drug toxicology tests rats are the primal test animals.

It has been shown that MIA injection to rat TMJ causes OA like lesions. Considering all above we selected the arthritis model induced by MIA injection in the rat TME joint. A simple and reliable rat model of TMJ OA have been described by Wang et al. (12) by intra- articular MIA injections.

Due to risk of serious complications, difficulty of surgical field, uncertainty of outcomes and low surgery motivation of patients, surgical treatment options are indicated and possible only in certain select group of TMJ OA patients. Intraarticular corticosteroid injection is widely used in OA treatment. Although single intraarticular injections have successful results in relieving symptoms, complications such as cartilage damage, bone necrosis, soft tissue atrophy lead to progression of existing joint disease in repeated injections. It is suggested that intraarticular corticosteroid injection reduces inflammation in rat TMJ but increases osteoclastic activity in the condyle and intraarticular injection of this substance may increase bone resorption risk. Harmful side effects of corticosteroids have also prompted the search for new therapeutic agents (13). Duygu et al. (14) demonstrated that intra-articular injection of hyaluronic acid (HA) decreased the cartilage changes in early stage OA in rabbit TMJ but there is no clinical consensus over HA usage and effects so far.

PRP also termed autologous platelet gel is essentially an increased concentration of autologous platelets suspended in a small amount of plasma after centrifugation at 2 different frequencies. PRP is a natural source of growth factors such as PDGF, IGF, VEGF, EGF, FGF and TGF- $\beta$ (15).

The amount of platelet obtained is 3-8 times that of normal plasma. A large number of mediators are released from the $\alpha$-granules of the platelets by the addition of thrombin to this product. Almost all of these are mediators that are involved in wound and bone healing and are also effective on angiogenesis. Clinical trials showed that it accelerates the bone and wound healing, decreases the swelling, pain, infection and scar formation, and helps the hemostasis (16). Hancl et al. (17) showed the effect of PRP on TMJ disorders and compared with arthrocentesis. Hegab et al. (18) demonstrated the effect of PRP on OA and compared with HA injections. Although these clinical studies are valuable, assessment of effects is subjective as it depends on patient surveys.

Because of autologous production, this product has been used clinically without adequate experimental study. It promises a lot theoretically but still has suspicions due to absence of adequate controlled studies. In this study, we investigated the effect of intraarticular PRP in the TMJ OA model induced by MIA injection and interpreted the results histologically which is not present and possible in clinical studies.

Increased degenerative changes, increased subchondral cyst formation and decrease in cartilage 
thickness were detected in the MIA induced arthritis group when compared with other groups. This finding indicates that MIA injection to the upper compartment of TMJ successfully formed an arthritis model consistent with the literature.

Increased cartilage thickness and decreased subchondral cyst formation and degenerative changes in the study group compared to the arthritis model demonstrate the protective effect of PRP administration on the degenerative effects of arthritis. A significant decrease in cartilage changes was found in control and study group and MIA group between at $12^{\text {th }}$ weeks $(p<0.05)$. Cartilage damage and cartilage matrix degradation is prevented by the anti-inflammatory effects of PRP.

Inflammation was statistically increased in the MAI group and in study group there were no statistically meaningful difference between the control groups which suggests the anti-inflammatory protective activity of PRP. Subchondral cyst formation even exists in PRP group there were statistically meaningful increase in MIA group. These findings all together points beneficial role of PRP derived cytokines and growth hormones in repair of $\mathrm{OA}$ in the joint.

Failure to perform repetitive PRP injection, lack of electron microscopic and micro CT scanning examinations are the weaknesses of this study but we think that PRP application, which is still used in other joint arthritis treatment, has a place in treatment of TMJ OA especially in patients who are not suitable for advanced surgery.

\section{Conclusion}

Further randomized clinical and experimental studies are needed to clarify the effects of PRP administration and we also believe that stem cell and PRF applications may be informative and supportive on clinical use of the role of PRP.

\section{Ethics}

Ethics Committee Approval: This study was approved by the Adnan Menderes University Faculty of Medicine Animal Ethics Committee (no: 645831012015-113).

Informed Consent: All experimental procedures were carried out in accordance with the Laboratory Animal Care and Use Health Guide National Institutes.

Peer-review: Externally and internally peerreviewed.

\section{Authorship Contributions}

Surgical and Medical Practices: H.S.Ö., S.I., H.K., T.D.Y., K.Ç., Concept: H.S.Ö., S.I.., Design: H.S.Ö., S.I.., Data Collection or Processing: H.S.Ö., S.I., Analysis or Interpretation: H.S.Ö., S.I., C.T., Literature Search: H.S.Ö., S.I.., Writing: H.S.Ö., S.I.., H.K., T.D.Y., K.Ç.

Conflict of Interest: No conflict of interest was declared by the authors.

Financial Disclosure: This study was supported by grant no: TPF-14011 from the ADU BAP (Adnan Menderes. University Scientific Support Programme) research Programme.

\section{References}

1. Stegenga B, de Bont LG, Boering G, van Willigen JD. Tissue responses to degenerative changes in the temporomandibular joint: a review. J Oral Maxillofac surg 1991: 49: 1079-88.

2. Stegenga B, de Bont LG, Boering G. Osteoarthrosis as the cause of craniomandibular pain and dysfunction. J Oral Maxillofac Surg 1989: 47: 249-56.

3. Dworkin SF, LeResche L. Research diagnostic criteria for temporomandibular disorders: review, criteria, examinations and specifications, critique. J Craniomandib Disord 1992; 6: 30155.

4. Zarb GA, Carlsson GE. Temporomandibular disorders: osteoarthritis. J Orofac Pain 1999; 13: 295-306.

5. Xinmin $Y$, Jian $H$. Treatment of temporomandibular joint osteoarthritis with viscosupplementation and arthrocentesis on rabbit model. Oral Surg Oral Med Oral Pathol Oral Radiol Endod 2005; 100: 35-8.

6. Brandt KD. Animal models of osteoarthritis. Biorheology 2002; 39: 221-35.

7. er N, Kürkçü M, Duygu G, Cam B. Sodium iodoacetate induced Osteoarthrosis model in rabbit temporomandibular joint: CT and histological study (Part I). Int J Oral Maxillofac Surg 2011;40:1289-95.

8. Chahal J, Van Thiel GS, Mall N, Heard W, Bach BR, Cole BJ, et al. The role of platelet-rich plasma in arthroscopic rotator cuff repair: a systematic review with quantitative synthesis. Arthroscopy 2012; 28:1718-27.

9. Hall MP, Band PA, Meislin RJ, Jazrawi LM, Cardone DA. Plateletrich plasma: current concepts and application in sports medicine. J Am Acad OrthopSurg 2009; 17:602-8.

10. Manfredini D, Rancitelli D, Ferronato G, Guarda-Nardini L. Arthrocentesis with or without additional drugs in temporomandibular joint inflammatory-degenerative disease: comparison of six treatment protocols. J Oral Rehabil 2012; 39: 245-51.

11. Bendele AM. Animal models of osteoarthritis. J Musculoskelet Neuronal Interact 2001; 1: 363-76.

12. Wang XD, Kou XX, He DQ, Zeng MM, Meng Z, Bi RY, et al. Progression of cartilage degradation, bone resorption and 
pain in rat temporomandibular joint osteoarthritis induced by injection of iodoacetate. PLoS One 2012; 7: e45036.

13. Liu F, Steinkeler A. Epidemiology, diagnosis, and treatment of temporomandibular disorders. Dent Clin North Am 2013; 57 : 465-79.

14. Duygu G, Güler N, Cam B, Kürkçü M. The effects of high molecular weight hyaluronic acid (Hylan G-F 20) on experimentally induced temporomandibular joint osteoartrosis: part II. Int J Oral Maxillofac Surg 2011; 40: 1406-13.

15. Marx RE. Platelet-rich plasma: evidence to support its use. J Oral Maxillofac Surg 2004; 62: 489-96.
16. Lopez-Vidriero E, Goulding KA, Simon DA, Sanchez M, Johnson $\mathrm{DH}$. The use of platelet-rich plasma in arthroscopy and sports medicine: optimizing the healing environment. Arthroscopy 2010; 26: 269-78.

17. Hancı M, Karamese M, Tosun Z, Aktan TM, Duman S, Savaci N. Intra-articular platelet-rich plasma injection for the treatment of temporomandibular disorders and a comparison with arthrocentesis. J Craniomaxillofac Surg 2015; 43: 162-6.

18. Hegab AF, Ali HE, Elmasry M, Khallaf MG. Platelet-rich plasma injection as an effective treatment for temporomandibular joint osteoarthritis. J Oral Maxillofac Surg 2015; 73: 1706-13. 